\title{
FROZEN GROUND AND SNOW COVER MONITORING IN THE SOUTH SHETLAND ISLANDS, ANTARCTICA: INSTRUMENTATION, EFFECTS ON GROUND THERMAL BEHAVIOR AND FUTURE RESEARCH
}

\author{
M.Á. DE PABLO ${ }^{1 *}$, M. RAMOS ${ }^{2}$, A. MOLINA ${ }^{1}$, G. VIEIRA ${ }^{3}$, M.A. HIDALGO ${ }^{2}$, \\ M. PRIETO ${ }^{4}$, J.J. JIMÉNEZ ${ }^{2}$, S. FERNÁNDEZ ${ }^{5}$, C. RECONDO ${ }^{6}$, \\ J.F. CALLEJA ${ }^{7}$, J.J. PEÓN ${ }^{6}$, C. MORA ${ }^{3}$
}

\begin{abstract}
${ }^{1}$ Department of Geology, Geography and Environment, University of Alcalá, Madrid, Spain. ${ }^{2}$ Department of Physics and Mathematics. University of Alcalá. Madrid, Spain. ${ }^{3}$ Centro de Estudos Geográficos IGOT, Universidade de Lisboa, Portugal. ${ }^{4}$ Department of Automatics. University of Alcalá. Madrid, Spain. 5 Department of Geology. University of Oviedo, Spain. ${ }^{6}$ Department of Mining Exploitation and Prospecting. University of Oviedo, Spain. ${ }^{7}$ Department of Physics. University of Oviedo, Spain.
\end{abstract}

\begin{abstract}
The study of the thermal behavior of permafrost and active layer on the South Shetland Islands, in the western side of the Antarctic Peninsula (Antarctica), has been our research topic since 1991, especially after 2006 when we established different active layer thickness and ground thermal monitoring sites of the CALM and GTN-P international networks of the International Permafrost Association. Along this period, the snow cover thickness did not change at those sites, but since 2010, we observed an elongation on the snow cover duration, with similar snow onset, but a delay on the snow offset. Due to the important effects of snow cover on the ground thermal behavior, we started in late 2015 a new research project (PERMASNOW) focused on the accurate monitoring of the snow cover (duration, density, snow water equivalent and distribution), from very different approaches, including new instrumentation, pictures analysis and remote sensing on optical and radar bands. Also, this interdisciplinary and international research team intends to compare the snow cover and ground thermal behavior with other monitoring sites in the Eastern Antarctic Peninsula where the snow cover is minimum and remains approximately constant.
\end{abstract}

Suelos congelados y manto nival en las islas Shetland del Sur, Antártida: instrumentación, efectos en el régimen térmico del suelo y futuras investigaciones

RESUMEN. El estudio del comportamiento térmico del permafrost y la capa activa en las islas Shetland del Sur, en el lado oeste de la Península Antártica (Antártida), ha sido el objeto de estudio de nuestro equipo de investigación desde 1991, y especialmente desde el año 2006 con la instalación de diversas estacio- 
nes de monitorización incluidas en las redes internacionales CALM y GTN-P de la Asociación Internacional del Permafrost. A lo largo de este periodo la cubierta nival no ha variado en su espesor aproximado de forma relevante, si bien hemos podido observar un importante incremento en la duración de dicha cubierta de nieve en todos los emplazamientos de estudio desde 2010. A pesar de que la fecha de inicio de las nevadas no se ha modificado, sí que se ha retrasado el momento de la desaparición de dicho manto de nieve, llegando en algunos lugares a no desaparecer. Dado el importante efecto que la nieve puede tener en el comportamiento térmico de los suelos, este equipo de investigación ha iniciado en 2015 un nuevo proyecto de investigación (PERMASNOW) centrado en el estudio detallado de la cubierta de nieve, incluyendo su duración, densidad, equivalente en agua y distribución. Para ello se usarán múltiples enfoques, incluyendo la instalación de nueva instrumentación especialmente dedicada al estudio de la nieve, el análisis de fotografías para la realización de cartografías de distribución de la nieve, y análisis de imágenes de satélite, tanto en el rango óptico como radar. Este equipo multidisciplinar e internacional también llevará a cabo la comparación de los datos de las zonas de estudio en las Shetland del Sur, con los que han tomado otros equipos de investigación en otros puntos de estudio térmico de los suelos en el lado este de la península ibérica, donde la cubierta de nieve es menos importante y está permaneciendo estable en cuanto a espesor y duración.

Key words: permafrost, active layer, snow cover, Antarctica.

Palabras clave: permafrost, capa activa, nieve, Antártida.

Received 15 December 2015 Accepted 22 January 2016

*Corresponding author: Departamento de Geología, Geografía y Medio Ambiente, Edificio de Ciencias, Campus Científico-Tecnológico, Universidad de Alcalá. 28871 Alcalá de Henares, Madrid, Spain. E-mail: miguelangel.depablo@uah.es

\section{Introduction}

Polar environments are not only characterized by extensive areas covered by ice and glaciers. Some regions at polar latitudes can remain free of ice, although the ground is maintained frozen year after year (permafrost). In high latitude regions, the harsh and cold climate conditions freeze the ground in winter. Conversely, the relative warmer weather conditions allow the permafrost to thaw partially in summer. This part of the ground that freezes and thaws periodically across the soil surface energy exchange is named "active layer" (Williams, 1995).

Maximum Active Layer Thickness (ALT) changes from year to year depending on the soil surface energy balance, and plays an important role, for example, on the formation of different periglacial landforms. Patterned ground, gelifluction lobes, stone rivers, polygonal terrain or stone circles, are a few examples of the landforms caused 
by freeze/thaw processes in the ground near surface (French, 1996). Although changes in the ALT result in visible effects on the surface, the underlying permafrost can also aggregate or degrade.

Two decades ago, different monitoring sites were established to study the evolution of the maximum ALT and the ground thermal behaviour. All of them are included in the Circumpolar Active Layer Monitoring (CALM), and Ground Terrain NetworkPermafrost (GTN-P) international networks, which were created by the International Permafrost Association (IPA) (e.g., Brown et al., 2000; Matsuoka, 2006; Nelson and Shiklomanov, 2009; Vieira et al., 2010). However, in the Southern Hemisphere, the presence of the permafrost monitoring sites is scarce.

Research on permafrost in Antarctica is very interesting due to climate change evolution. It is well known that the Mean Annual Air Temperature (MAAT) in Antarctica Peninsula region increased locally at a rate of about $0.56^{\circ} \mathrm{C} / \mathrm{decade}$ in the last 60 years (Turner et al., 2005, 2009, 2013) causing, for example, the increase of the glaciers flow velocity, or the reduction of the extension of the ice pack covering the southern ocean, among other effects (e.g., Vaughan et al., 2003). The thermal evolution of the permafrost is directly related to the weather and climate conditions, especially when there is no vegetation on the soil surface, which is the case in most of the permafrost areas in Antarctica. An intensive monitoring of the permafrost in Antarctica should be relevant for the scientific community as the continuous record of the active layer and the permafrost thermal evolution can be used to detect the climate variability.

The $0.3 \%$ of the territory free of ice where permafrost could be studied is located at the edge of the continent. This includes the South Shetland Islands, in the Western Antarctic Peninsula (AP). The South Shetland Islands Archipelago (Fig. $1)$ is located immediately below the Southern Polar Circle $\left(61^{\circ} 55^{\prime} \mathrm{S}-63^{\circ} 30^{\prime} \mathrm{S}\right.$; $57^{\circ} 45^{\prime} \mathrm{W}-61^{\circ} 30^{\prime} \mathrm{W}$ ), at about $1000 \mathrm{~km}$ from Tierra del Fuego in South America. This archipelago is one of the Antarctic regions located at lower latitude, where the MAAT is about $-2^{\circ} \mathrm{C}$ (Weyant, 1966). In summer, the mean seasonal air temperature can rise up to $2^{\circ} \mathrm{C}$ (Vieira et al., 2010; Bañon and Vasallo, 2015). It means that under these weather conditions, the frozen soils can thaw in summer, and any increase in the air temperatures due to global warming will contribute to increase the active layer and to degrade the permafrost, what could be detected by continuous monitoring. This sensibility makes this region adequate to monitor the permafrost and the active layer thermal and mechanical evolution (e.g., Bockheim, 1995; Vieira et al., 2010; Bockheim et al., 2013).

The effect of the snow layer on the soil surface is also very important since the energy balance across the snow is a function of the snow layer thickness and its thermodynamic characteristics (thermal diffusivity), which are both related to the snow morphological characteristics (e.g., Goodrich, 1982; Zhang, 2005). In the South Shetland Islands (Western Antarctic Peninsula), the annual precipitation is about 500-800 mm (Bañon and Vasallo, 2015), higher than the precipitation in the Eastern AP, such as in the James Ross Island, where annual snow precipitation is about 100-200 mm (King et al., 2003), although some authors report higher values (300-500 mm; Lipzig et al., 2004). 

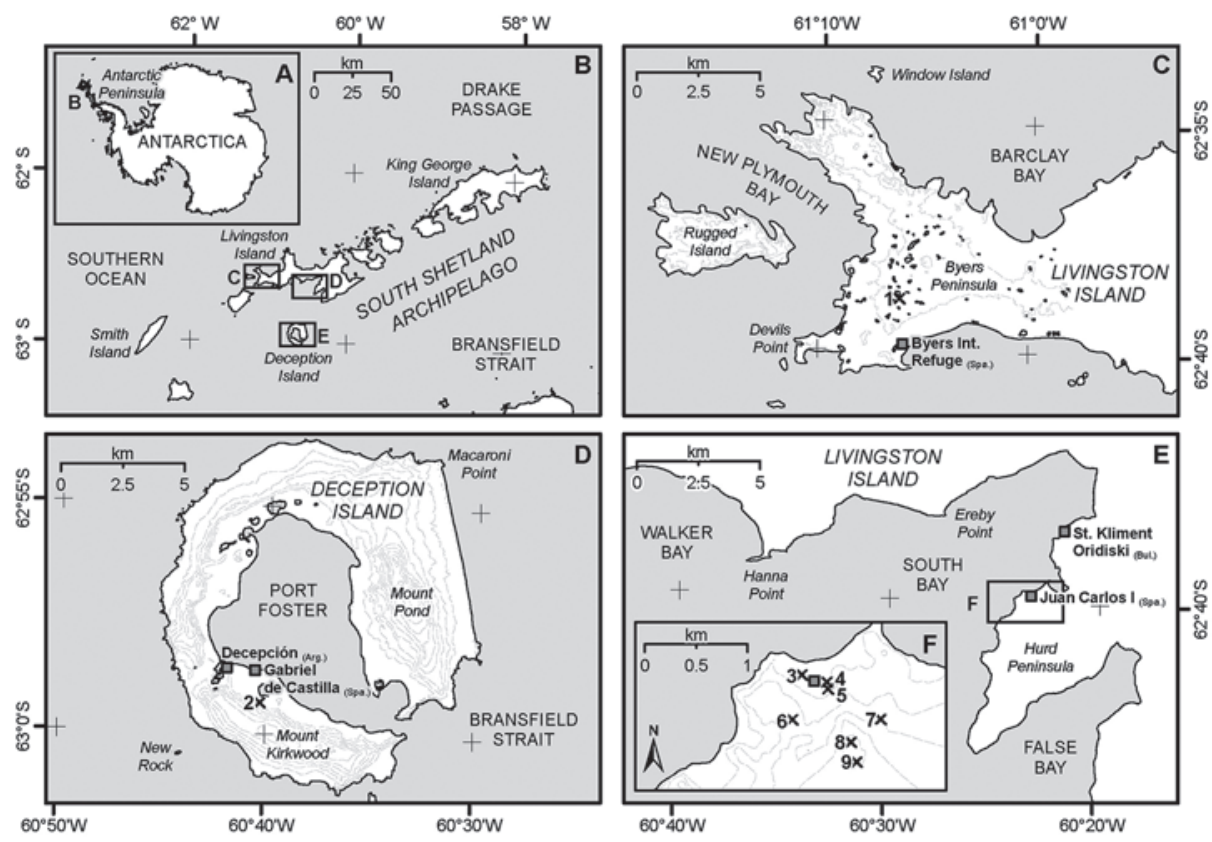

\begin{tabular}{|c|c|c|c|c|}
\hline \multicolumn{2}{|c|}{ Legend } & \multicolumn{3}{|l|}{ Monitoring sites: } \\
\hline$x$ & Monitoring sites & 1. Limnopolar Lake & 4. Incinerador & 7. Morrena \\
\hline a & Antarctic Stations & 2. Crater Lake & 5. Nuevo Incinerador & 8. Glaciar \\
\hline & Contour lines $(50 \mathrm{~m})$ & 3. BAE JCl & 6. Collado Ramos & 9. Reina Soffia \\
\hline
\end{tabular}

Figure 1. Location map of the monitoring sites in Livingston and Deception Islands, South Shetland Archipelago, Antarctica.

In this scenario, the active layer and permafrost monitoring in Antarctica should be considered a priority research topic. In fact, this was the research topic of our team since 1991, particularly after 2006 with the inclusion of several stations in Livingston and Deception Islands belonging to the CALM and GTN-P networks. Here we show how permafrost and snow are monitored in these stations as well as a few examples of the characteristics and evolution of the ALT and permafrost thermal behavior in both islands. Due to the changes observed in the snow cover thickness, we also present the instrumentation and methods that we will apply to improve our monitoring of the snow cover in the next years.

\section{Active layer and permafrost thermal monitoring in the South Shetland Islands}

Our research team started in the late 80 s with the study of meteorological and micrometeorological parameters in the South Shetland Islands (Ramos, 1995; 1997, 1998). At the same time we started to work in mountain permafrost in the frame of the European research program PACE in the Sierra Nevada mountain (Spain) (Gómez et al., 2001; Tanarro et al., 2001). The main goal was to study the permafrost in Livingston and Deception 
Islands (Antarctica), at different sites near the Spanish Antarctic Station (SAS) "Juan Carlos I" and "Gabriel de Castilla", respectively (Fig. 1). Different field experiments and instrumentation were installed to measure soil and air parameters (temperature, humidity, solar radiation balance, among others) (Ramos, 1995, 1997, 1998). In 2001, the Alcalá University (UAH) research group started an important collaboration with a Portuguese team from the University of Lisbon (UL) interested in the permafrost and active layer too. This collaboration resulted in the establishment of a growing number of monitoring stations of active layer and ground temperature, initially in Livingston and Deception Islands (Fig. 1), but later extended to King George Island, also in South Shetland Archipelago, Anvers Island or Cierva Cove, in the AP. Some of the monitoring stations grew thanks to the collaboration with other teams from Argentina, Brazil, Bulgaria, Czech Republic, Russia, Switzerland or the United States. These collaborations allowed to expand the CALM and GTN-P network in the South Shetland Islands and other parts of the AP (Bockheim, 1995; Vieira et al., 2010; Bockheim et al., 2013).

The CALM network intends to monitor the active layer thickness and its evolution along the time (Brown et al., 2000). It started in the Arctic and it was later extended to Antarctica under the CALM-S acronym, although only a few sites have been installed until now (e.g. Vieira et al., 2010). The protocol of this network establishes different methods to monitor the active layer. One of them proposes the use of mechanical probing as a technique to measure the active layer thickness. This technique consists on the sinking of a metal rod ( $1 \mathrm{~cm}$ in diameter) into the ground until the top of the permafrost is reached; this is based on the idea that the thawed soils allow the penetration of the rod, but not the frozen ground. This technique is not perfect, requires experience from the operator, and it can be only applied to non-stony or rocky soils because otherwise it is not possible to distinguish the frozen ground. Measurements are repeated to reduce errors caused by stones or the operator, and a mean value is used at each site. Moreover, due to the spatial variability of the permafrost, measurements should be repeated at different sites in the same region to derive a regional value of the mean active layer thickness in the area. The use of this technique allows, if repeatedly applied, to analyze the evolution of the freezing/thawing process along the year and, for a long term monitoring, to determine interannual variations of the active layer thickness. To achieve this, it is required to measure always at the same sites. For this reason, the protocol proposes the establishment of a square grid (between 10 and $1000 \mathrm{~m}$ in side, with nodes each 1 to $100 \mathrm{~m}$, respectively), marked with stacks to measure the active layer thickness by mechanical probing in all the nodes of the grid. Those grids are identified as CALM sites. Homogeneous terrains are preferred to derive mean values of the active layer that are representative of the area. This technique can also be applied only once per year at the end of the thaw season, allowing to derive the maximum ALT for that year. When it is measured in any other date, it represents the thaw depth at the measuring date. When temperature data are available, the measured thaw depth can be compared to the active layer derived from temperature data, as we describe below.

In Deception Island we have established two CALM-S sites, one of them in 2006 near the Crater Lake (Crater Lake CALM site-A16) (Ramos et al., 2011a) and another one in 2010 on the slope of the Mount Irizar (Irizar CALM site) (Vieira et al., 2010). 
In Livingston Island, we tried to establish three sites in Hurd Peninsula but the terrain is stony or rocky and it was not possible to measure the active layer with this technique (mechanical probing). Finally, we were able to establish in early 2009 a CALM-S site in the basin of the Limnopolar Lake in Byers Peninsula of Livingston Island (Limnopolar Lake CALM site -A25) (de Pablo et al., 2010, 2013, 2014). All these sites are 100x100 m grids, with nodes each $10 \mathrm{~m}$, where the active layer thickness is measured in late January and early February.

The GTN-P network is focused on the thermal monitoring of the ground to obtain the thermal permafrost evolution by direct measurements and the thickness of the permafrost by indirect methods. The thermal monitoring of ground is based on the installation of an array of temperature sensors into a borehole whose depth depends on how far the operator can drill, depending on the thickness of the permafrost. There is not a specific sensor to be used, although the use of micro-sensors is widely extended, such as iButtons (from Maxim), TinyTag (from Gemini) or Hobbo (from Onset). In other cases, the arrays of sensors are connected to a datalogger at the surface, which requires batteries and solar cells. Usually, when a datalogger is used, other meteorological parameters are also measured at the surface, like air temperature and humidity, snow depth, wind speed, and/ or solar radiation (Ramos et al., 2009). All those data help to develop energy balance models that can be used to understand and to model the evolution of the thermal state of permafrost and to calculate indirectly the ground thermodynamics parameters (Correia et al., 2012).

Snow depth is also a key parameter. Its measurement requires the use of complex electronic devices (such as infrared, laser, or ultrasonic sensors). Another option is to use an array of temperature loggers at different heights in the same mast. In this way, air temperature measured at different elevations is used to derivate if one of those sensors has been covered by snow. This is based on the idea that the thermal inertia of a sensor covered by snow is different than that of a sensor measuring at the same time and located only a few centimeters above the snow cover surface but without snow cover. The resolution of the snow depth with this method is given by the distance between the different sensors in the array, and the frequency of the temperature measurements (Molina et al., 2011). Different studies about the isolation effect of the snow show that a thickness of 30 to $70 \mathrm{~cm}$ of snow is enough to isolate the ground from the environmental temperatures in a seasonal regimen (e.g., Goodrich, 1982; Zhang et al., 1996; Zhang, 2005). Based on this principle, in some other cases a temperature sensor located at just only $2-5 \mathrm{~cm}$ below the ground surface to avoid direct solar radiation heating is used to derive the presence or not of a snow cover (without the possibility of determining its thickness). Moreover, the data from surface temperature can be combined with air temperature data to derive the n-factor (Williams, 1995; Andersland and Ladanyi, 1994), which is a way to quantify the isolation effect of the layers on top of the ground (like soils, vegetation, or snow), based on the calculation of freezing indices (Williams, 1995; Andersland and Ladanyi, 1994).

Although the combination of ground temperatures and air, surface and snow temperatures is not enough to develop complete energy balance calculations and models, they are sufficient, not only to thermally characterize and monitor the active layer and the 
permafrost, but also to analyze the relation between the environmental temperature and the role of the snow cover. Moreover, this kind of instruments is relatively cheaper than complex instruments, which also require more complex installations. For that reason, our research team progressively installed stations of this type (Fig. 2) in Deception and Livingston Islands. In Deception Island, there are more than four stations at the Crater Lake CALM site, and some other stations at the Irizar CALM and other monitoring sites. In Livingston Island, we have a station at the Limnopolar Lake CALM site in Byers Peninsula, and six other stations in Hurd Peninsula, from the sea level close to the Spanish Antarctic Station Juan Carlos I to the summit of the Mount Reina Sofía (about $265 \mathrm{~m}$ a.s.1.), allowing the study of the variation of the active layer with elevation. Other stations of this type are also distributed close to the Bulgarian Antarctic Station St. Kliment Ohridski in Hurd Peninsula and are maintained by the Portuguese part of the team. In the summit of the Mount Reina Sofía we also have two important boreholes of 15 and 25 m-deep (Ramos et al., 2009). The latter is the deepest borehole in this region of Antarctica, and its data are quite important for the GTN-P network, so it is equipped with an automatic logger to ensure the continuous and precise data acquisition.

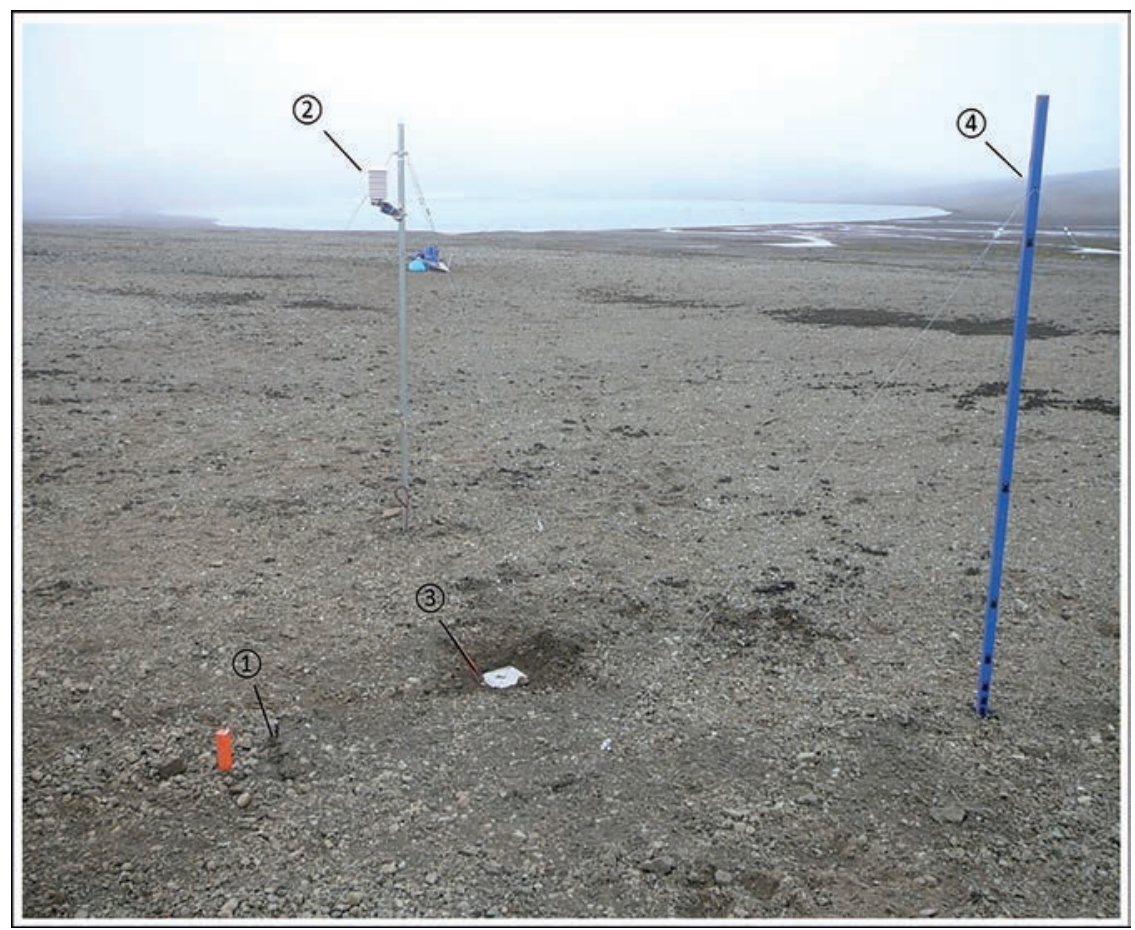

Figure 2. Example of a Thermal State of Permafrost (TSP) monitoring station (at the Limnopolar Lake CALM site, Byers Peninsula, Livingston Island), including (i) a borehole to monitor ground temperature, (ii) air temperature, (iii) ground surface temperature and (iv) snow depth obtained from air temperature at different heights. 


\section{Frozen ground and snow cover}

\subsection{Frozen ground}

The variety of instruments installed in Deception and Livingston Islands (e.g., Hauck et al., 2007; Ramos and Vieira, 2008; Ramos et al., 2009, 2011a, 2011b; de Pablo et al., 2010, 2011; Molina et al., 2011; Vieira et al., 2010, 2011a, 2011b) allowed, after nine years of continuous monitoring, the thermal characterization of the ground at the study sites (e.g., Ramos, 1997, 1998 ; Ramos and Vieira, 2004; Ramos et al., 2012a, 2012b; de Pablo et al., 2013 , 2014). The data do not show a clear trend in the permafrost evolution. Some data point to the thawing of the frozen grounds (Ramos et al., 2012a, 2012b; de Pablo et al., 2013, 2014), in agreement with the regional observations and analyses (Turner, 2005, 2009, 2013). However, the active layer thickness measured at the Crater Lake CALM site (Table 1) shows decreasing values since 2006, reducing from $35 \mathrm{~cm}$ in 2006 to $23 \mathrm{~cm}$ in 2014. This reduction in the active layer thickness has been also observed in the Limnopolar Lake CALM site in Livingston Island (Table 1), with a mean value of $47 \mathrm{~cm}$ in 2009 and $12 \mathrm{~cm}$ in 2013. It was not possible to measure the active layer thickness in 2014 and 2015 because of the presence of a thick snow cover (in spite of the fact that the measurement date was approximately the same than in previous years).

Table 1. Summary of active layer thickness at the Crater Lake CALM site in Deception Island, Antarctica.

\begin{tabular}{|c|c|c|c|c|c|c|c|c|c|c|}
\hline CALM Site & & $\mathbf{2 0 0 6}$ & $\mathbf{2 0 0 7}$ & $\mathbf{2 0 0 8}$ & $\mathbf{2 0 0 9}$ & $\mathbf{2 0 1 0}$ & $\mathbf{2 0 1 1}$ & $\mathbf{2 0 1 2}$ & $\mathbf{2 0 1 3}$ & $\mathbf{2 0 1 4}$ \\
\hline \multirow{4}{*}{$\begin{array}{c}\text { Crater } \\
\text { Lake }\end{array}$} & Mean $(\mathrm{cm})$ & 35.5 & 32.0 & 32.2 & 33.8 & 31.5 & 27.6 & 28.7 & 23.2 & 23.1 \\
\cline { 2 - 11 } & Max. $(\mathrm{cm})$ & 44.0 & 38.0 & 39.0 & 39.0 & 40.0 & 34.0 & 34.0 & 37.0 & 33.5 \\
\cline { 2 - 11 } & Min. $(\mathrm{cm})$ & 29.0 & 21.5 & 26.0 & 28.0 & 24.0 & 19.5 & 23.0 & 5.0 & 14.5 \\
\cline { 2 - 11 } & STD $(\mathrm{cm})$ & 2.5 & 3.2 & 2.9 & 2.3 & 3.0 & 2.8 & 2.5 & 6.9 & 4.3 \\
\hline \multirow{4}{*}{$\begin{array}{c}\text { Limnopolar } \\
\text { Lake }\end{array}$} & Mean $(\mathrm{cm})$ & - & - & - & 46.8 & 43.4 & 40.5 & 39.1 & 11.7 & - \\
\cline { 2 - 10 } & Max. $(\mathrm{cm})$ & - & - & - & 105.0 & 99.0 & 85.0 & 105.0 & 47.7 & - \\
\cline { 2 - 10 } & Min. $(\mathrm{cm})$ & - & - & - & 8.0 & 7.0 & 6.0 & 9.0 & 0.0 & - \\
\cline { 2 - 10 } & STD $(\mathrm{cm})$ & - & - & - & 28.5 & 18.8 & 19.5 & 22.2 & 13.8 & - \\
\hline
\end{tabular}

During the same period, ground surface temperatures show decreasing thermal ranges, with lower maxima and higher minima, but without any significant trend, despite the fact that the air temperatures have been quite similar along the study period, as we can observe on the data from the GTN-P data in Limnopolar Lake site (Fig. 3).

The thermal profiles of the ground, based on the analyses of 2009-2014 maximum, minimum and mean temperatures at different depths in the boreholes, allows to characterize the ground temperature at each site, and to determine the active layer thickness (which is compared with the thaw depth measured in the nearest CALM site where possible) and the permafrost thickness when it is completely crossed by the borehole. This allows, for example, to establish the presence of an active layer of about $70 \mathrm{~cm}$ in the Crater Lake monitoring site, on top of a $4.5 \mathrm{~m}$ thick permafrost, whose temperature is slightly lower than $0^{\circ} \mathrm{C}$ (Fig. 4). In other sites, the active layer is very thin (lower than $20 \mathrm{~cm}$ ), like on top of at least $15 \mathrm{~m}$ permafrost thickness (our borehole does not cross it completely), with temperature lower than $2^{\circ} \mathrm{C}$. 


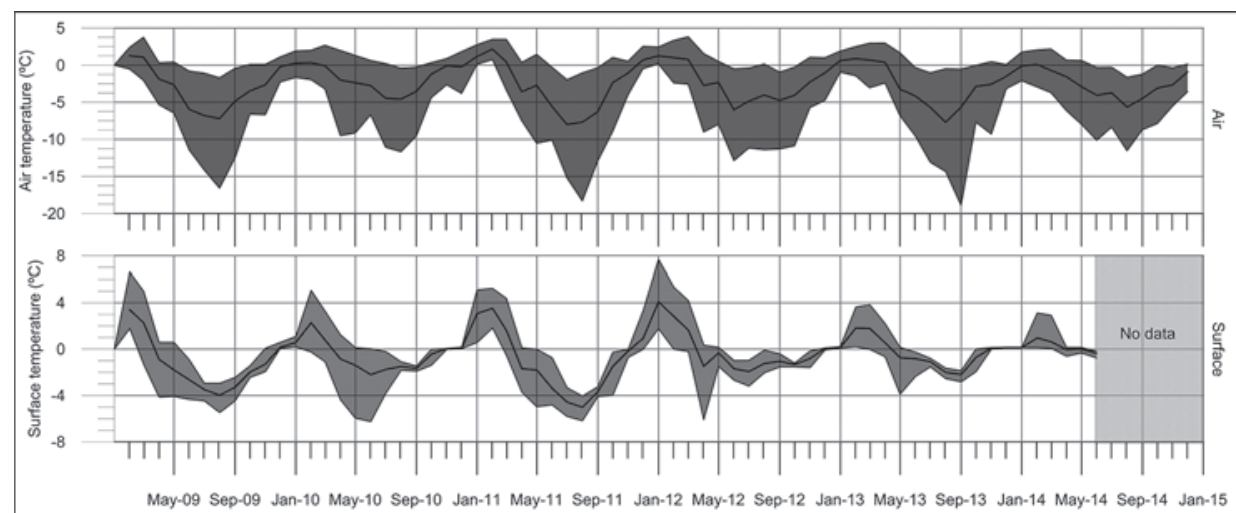

Figure 3. 2009-2015 air (top) and ground surface (bottom) monthly maximum, mean and minimum temperatures at the Limnopolar Lake monitoring site, showing the similar behavior on air temperatures, but a reduction of the temperature range at the ground surface during the study period, mainly since 2012 (from de Pablo et al., 2016).

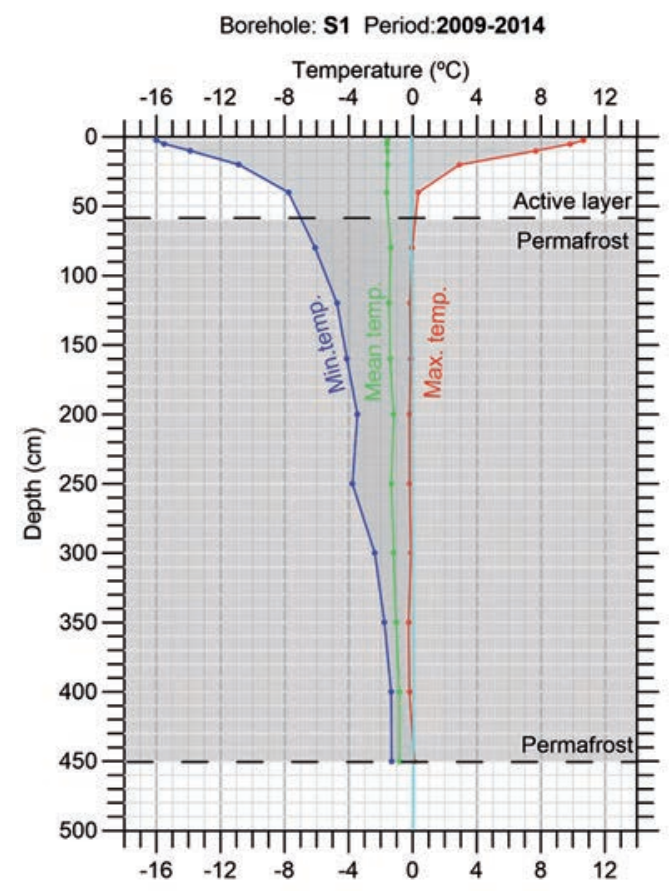

Figure 4. Example of thermal profiles derived from ground temperatures monitored since 2009 at one of the boreholes at the Crater Lake CALM site (Deception Island), showing the active layer thickness of about $60 \mathrm{~cm}$, and a permafrost layer of about $4 \mathrm{~m}$ thick. The mean temperature in the ground is about $0^{\circ} \mathrm{C}$, revealing very sensible permafrost, which could be quickly affected by a possible air temperature increase as well as a change in the snow cover regime. 
In a similar way, boreholes in the monitoring sites close to the Juan Carlos I Antarctic Station in Livingston Island show a reduction in the ground temperature ranges at different depths, and a trend of the temperatures towards $0^{\circ} \mathrm{C}$. This is the case of the borehole located in the proximity of the Mount Reina Sofía, a 15 m deep borehole drilled in 2008 (Ramos et al., 2009) at about $280 \mathrm{~m}$ a.s.l. The mean ground temperature progressively declines in the profile, although it remains slightly lower than $-2^{\circ} \mathrm{C}$, and the temperature range also decreases (Fig. 5). An important fact is that the borehole was drilled in a snowfree site near the mount summit, and since then the snow cover has increased continuously. Although there is no devices to measure the snow cover depth, the regular visit to this place over the years to get the data from the temperature sensors inside the borehole, allows to confirm that the snow does not disappear. It has increasedfrom year to year until reaching more than $3 \mathrm{~m}$ of ice and snow in February 2015 (Fig. 6). Nowadays, this site could not be considered anymore a site free of ice.

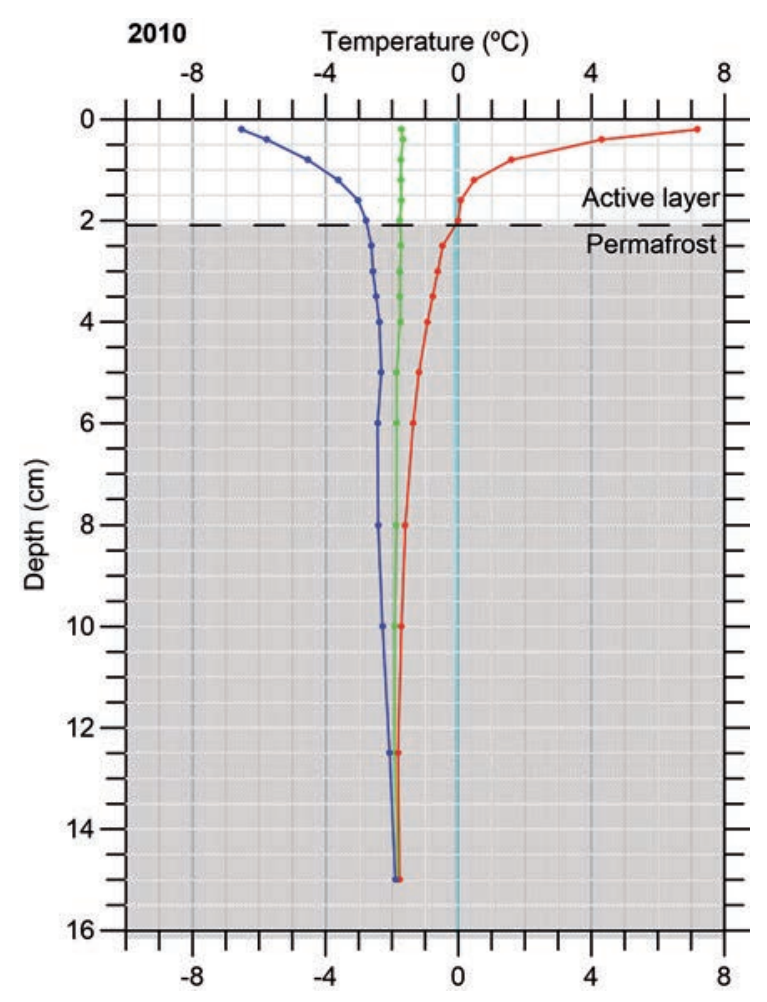

Figure 5. Example of a thermal profile of a $15 \mathrm{~m}$ deep borehole close to the summit of Mount Reina Sofía, Livingston Island. 


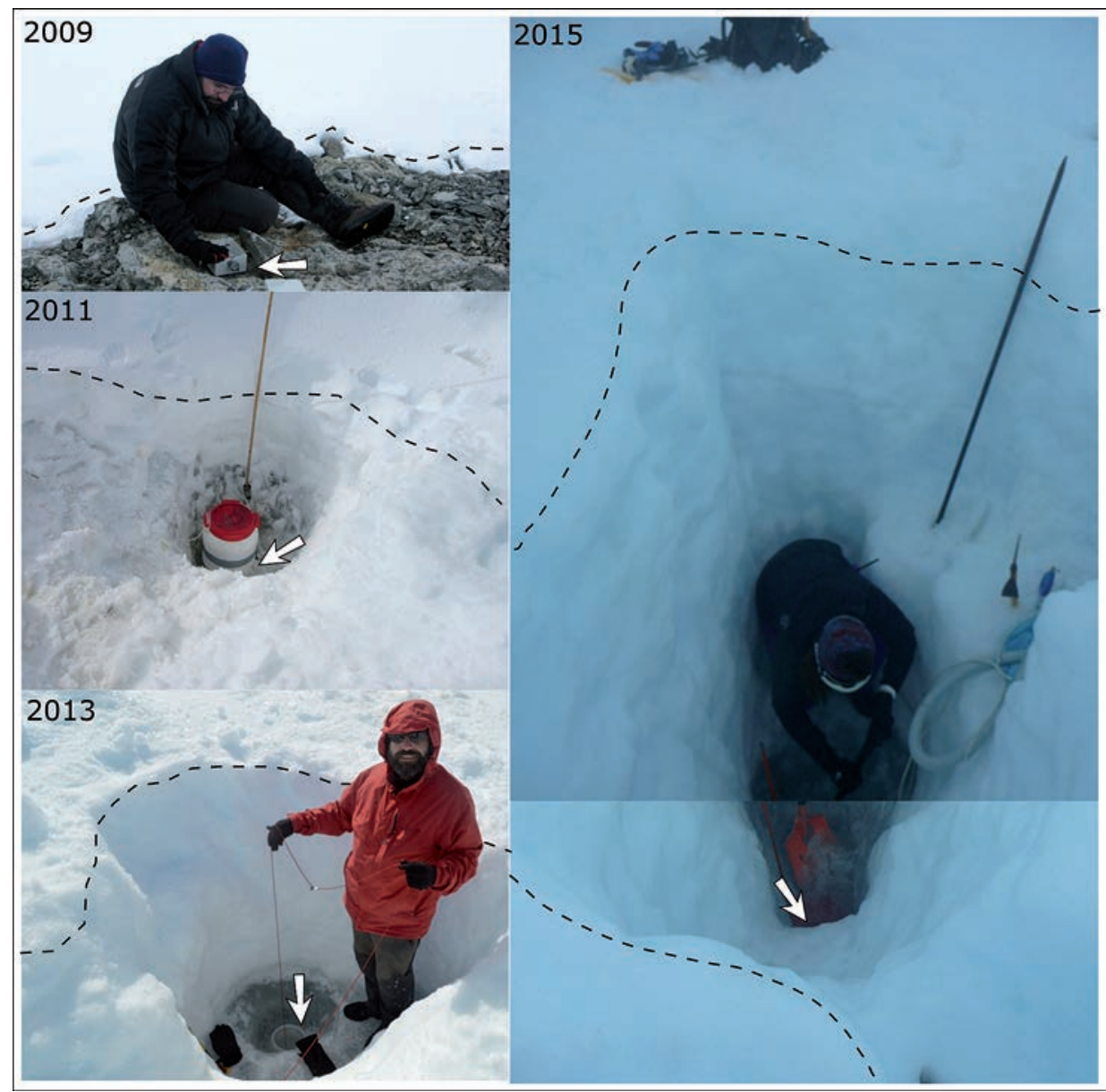

Figure 6. Snow cover duration in all the monitoring sites, showing an increasing trend. In one case, the snow cover did not disappear during the Antarctic summer since 2010, causing an increasing ice and snow layer that in January 2015 reached more than $3 m$ (the white arrow marks the position of the borehole, and the dashed line the snow cover surface).

Usually there are important difference in the thermal behavior of the ground depending on its nature (soil or bedrock), caused by the different grain-size, moisture, porosity, etc. However the data from the boreholes drilled in soils (Fig. 4) and bedrock (Fig. 5) show a similar pattern and behavior, discarding any possible lithology-related cause on the thermal behavior evolution.

\subsection{Snow cover}

The results obtained on the ground thermal behavior seem to be contradictory: the active layer thickness is reducing whereas ground temperatures tend to be less variable around $0^{\circ} \mathrm{C}$. Meanwhile, air temperature did not show remarkable changes during the 
study period. During the visits to our monitoring sites for maintenance operations in Antarctica we observed how, for the same date, snow cover was thicker each year. Considering the isolation effect of the snow (e.g., Goodrich, 1982; Zhang et al., 1996; Zhang, 2005, and references therein), we hypothesize that the changes in the snow cover are responsible for the observed ground thermal behavior at our monitoring sites.

We calculated the snow depth for all our monitoring sites near the Spanish Antarctic Stations in Livingston and Deception Islands, considering the daily variability of air temperature using sensors at different heights in a mast (Lewkowicz, 2008). Despite the low resolution in the snow cover height derived from the monitoring method, we could use it to study the snow cover under the same or different local characteristics (elevation, slope, aspect, wind conditions, relief, among others). Interannual variations of the snow depth were also observable, like between 2012 and 2013 in the Livingston Island (Fig. 7).

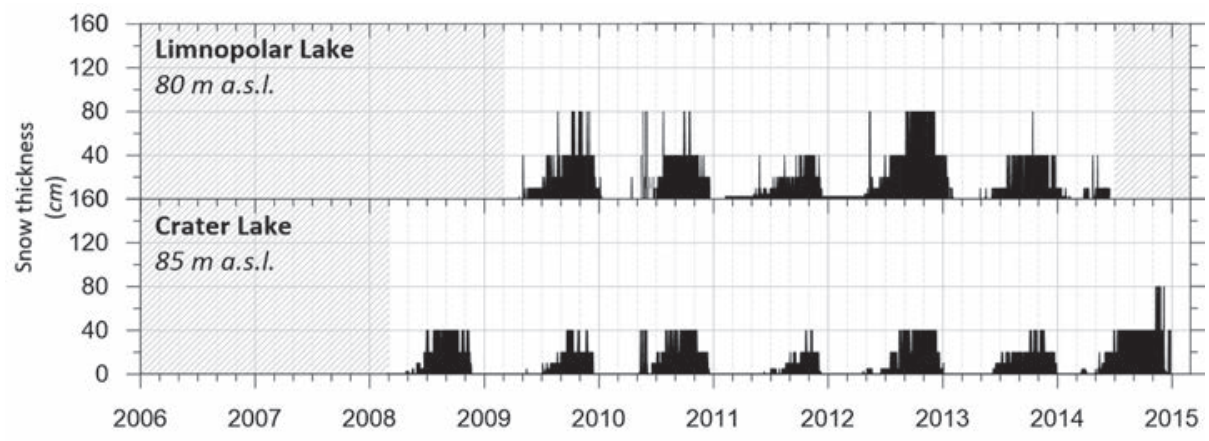

Figure 7. Example of the snow cover depth at two monitoring sites at Byers Peninsula in Livingston Island (top), and Crater Lake in Deception Island (bottom).

In general, we observed that the maximum snow depth did not change significantly over the study period in any of the sites, although there was a clear elongation in the snow cover duration in all the cases. We reported how the snow onset date did not change significantly, but the snow cover offset was delayed, in some cases, more than two months. This is the case, for example, of the snow cover period at the Limnopolar Lake monitoring site, which increased in more than 60 days in the last three years, i.e. from 267 to 338 days (de Pablo et al., 2016).

Considering that the air temperatures did not change significantly over the study period (Fig. 3) and because the snow depth remained similar, the behavior observed in ground temperatures could be related to the elongation of the snow cover. It is well known that snow cover behaves like an effective thermal insulator from the air temperature when it is about 30 to $60 \mathrm{~cm}$-thick (Goodrich, 1982, Zhang et al., 1996). However, our preliminary studies about the effective snow depth reported values of $20 \mathrm{~cm}$ from our monitoring sites (Jiménez et al., 2013, 2014). Except in selected sites, this snow depth was reached in almost all our monitoring sites in most of the years (Fig. 7). 
Based on these general observations, we hypothesize that snow cover evolution is changing in the monitoring sites, not significantly in depth, but in duration by the delay in the snow offset. Although the isolation effect of the snow cover may play an important role (e.g., Zhang, 2005), further research about the snow cover properties (e.g., density or snow water equivalent) should be conducted in order to make it possible to develop correlation models that could help to quantify the snow cover effect on the ground thermal behavior.

\section{Further research: techniques and methods}

\subsection{Snow cover monitoring}

Due to the relevant role of the snow cover on the thermal behavior in Deception and Livingston Islands, a more detailed study of the snow characteristics (i.e. snow onset, snow offset, thickness, density, and snow water equivalent) is required. This requires the use of more precise devices, and for that reason new instrumentation will be installed in the Crater Lake CALM site in late 2016, including an ultrasound sensor to measure snow depth and a Snow Pack Analyzer (SPA), by Sommer Company, to measure snow density and snow water equivalent. This site will also include a mast with an array of temperature sensors that could be compared with the data acquired by the temperature-based devices. Multiple masts of this type will be installed in each CALM site to interpolate the data to produce snow cover depth maps of the CALM site grid along the year, also with the help of high resolution digital cameras that will take a daily picture of the CALM site. Those maps will allow us to compare the snow cover properties and evolution with the active layer thickness measured in each node of the grid.

The correlation between the SPA snow thickness data and the temperature-based monitoring masts will allow to develop thickness models that will help us to increase the precision of the snow cover thickness in all our monitoring sites, even if they do not have their own SPA station. Additionally, these data acquired in the SPA station will contribute to extend the snow and ground thermal models to other surrounding areas where we do not have monitoring stations. In the future, they should contribute to develop permafrost distribution maps taking into account the snow characteristics.

In the study of the snow cover, active layer thickness, and ground thermal behavior, it will be relevant to develop comparative analyses with other regions of similar Antarctic climate conditions, although they register lower snow precipitation. This is the case of the CALM and GTN-P sites at the Ulu Peninsula on the James Ross Island, Eastern AP, under the responsibility of a research team from Czech Republic (e.g., Engel et al., 2010; Laska et al., 2012; Hrbáček et al., 2014, 2015). In this region of the Antarctica, although air temperatures are somewhat colder, there is a known correlation factor and the snow precipitation is lower than in South Shetland Archipelago (e.g., Hrbáček et al., 2016, and references therein). Annual and interannual comparative analyses between data from both monitoring sites will allow a better understanding, not only of the permafrost and active layer state and evolution related the global warming but also of the role of snow on the control of the thermal state of the ground. 


\subsection{Snow cover patterns}

In order to monitor the snow cover onset, offset and duration, as well as to check the data from air-temperature based snow monitoring devices, automatic digital cameras were installed to take pictures of the whole Crater Lake and Limnopolar Lake CALM sites in 2008 and 2009, respectively. We use a C640 (from Campbell) camera mounted on a mast at a $1.5 \mathrm{~m}$ height. The camera is programmed to take a daily picture (at noon GMT) in JPEG format in the visible spectral range, with a resolution of 0.7 Mpixels (480x640 pixels).

The pictures need to be georeferenced using an experimental complement of QGIS Pic2map (Produit and Tuia, 2012; Milani, 2014). This tool uses the digital elevation model (DEM) of the study area to obtain the coordinates of the elements in the pictures. The DEM can be complemented with the satellite image to obtain more detailed georeferencing points. The main objective is have a time series of snow cover melting maps in the CALM sites. This way the snow-melting patterns could be related to the maximum ALT measured each year, as well as with the thermal regime of permafrost. Also, the evolution of ground surface color in the CALM sites during the melting season could be measured using different color space models as Munsell HVC, RGB, decorrelated RGB (DRGB), CIEXYZ, CIELAB, CIELUV, CIELHC, and Helmholtz chromaticity coordinates (Viscarra Rossell, 2006). Previously, the analysis of relative shadow (RS) should be performed on each picture to obtain information about the pure color (Denis et al., 2014). Ground surface properties, like texture or composition, can be identified by differences in color (Escadafal, 1993) and can be related to the surface radiance (Coleman et al., 1990). Consequently, transference functions between RGB pictures and optical images obtained with a high spectral and spatial resolution satellite image (e.g. Worldview-2) could be performed to obtain models of the ground surface energy radiation and its variations during the snowmelt period and its relation to the permafrost thermal profiles recorded in the CALM sites.

\subsection{Remote sensing}

The multispectral sensors traditionally used for studies of snow cover and albedo are TM and ETM+ on board Landsat- 5 and Landsat-7, respectively ( 6 optical bands, 15 $30 \mathrm{~m}$ spatial resolution) (Tedstone et al., 2015), and the ASTER sensor onboard Terra spacecraft ( 9 optical bands, $15-30 \mathrm{~m}$ ). ASTER also provides stereoscopic vision in one band, from which the highest resolution digital elevation model on a global scale has been obtained (GDEM: Global Digital Elevation Model; Abrams et al., 2015). This model is necessary to quantify the snow cover thickness. The new OLI optical sensor on board Landsat- 8 (from 2013) ensures the continuity of these studies with the Landsat series. The spectral resolution of these images is appropriate for a good discrimination of snow cover and soil, while the spatial resolution of $15 \mathrm{~m}$ may be the most suitable for the study of the CALM meshes, whose nodes are separated $10 \mathrm{~m}$. Thus, we will be able to conduct spatial extrapolation of the ALT and permafrost thermal behavior, comparing the results obtained by remote sensing and field data. WorldView-2 images, with higher 
spatial and spectral resolutions (8 VNIR channels, 0.5-2.0 m) will also be used besides the Landsat and ASTER images.

The soil temperature measured in situ (Ts) and the air temperature (Ta) will be compared to the Land Surface Temperature (LST) obtained from the thermal bands (10-14 $\mu \mathrm{m})$ of sensors with distinct spatial resolutions. At a larger spatial scale we will use the LST products from MODIS with a spatial resolution of $1 \mathrm{~km}$. A series of cloud-free images will probably be obtained, given the high temporal resolution of MODIS data (1 day). Urban et al. (2013) compared the LST of several sensors with low spatial resolution with Ta from meteorological stations on a pan-Arctic scale (latitude $>60^{\circ} \mathrm{N}$ ) and concluded that MODIS LST had the highest correlation with Ta $(\mathrm{R}=0.95)$. Therefore, we will use MODIS LST products in this project. Landsat LST product with a spatial resolution of $100 \mathrm{~m}$ and ASTER LST product with a spatial resolution of $90 \mathrm{~m}$ will also be tested. Unfortunately, given the low temporal resolution of Landsat and ASTER (16 days), it will be more difficult to obtain a time series of cloud-free data.

The next step in the application of remote sensing data will be the assimilation of remote sensing albedo in an LSM (Land Surface Model). Data assimilation is the introduction of observations of a particular physical quantity or variable into a model to improve model predictions. This reduces the uncertainties inherent to simulations. In our case, the aim of this process will be to obtain the snow properties from satellite images. MODIS albedo product MOD10A1 has recently been assimilated in the Noah LSM. As a result, the snow depth and the duration of the snow season were obtained in a study area in Colorado, USA (Malik et al., 2012). This kind of research has not been carried out in Antarctica yet. In the future, we also intend to investigate the use of high spatial resolution albedo products and high spatial resolution imagery for the albedo assimilation in an LSM.

\subsection{Radar data}

Another approach to study the snow cover using remote sensing includes RADAR data (Jiménez, 2014), which is not limited by the presence of clouds, that are very frequent in the Antarctic region. The use of radar in the study of the snow cover has been tested mainly in the C-band $(4-8 \mathrm{GHz}$ or $3.75-7.50 \mathrm{~cm})$, and scarcely in the X-band (8-12 GHz or 2.50-3.75 cm) (Rees, 2006). In fact, whereas the use of data in the C-band provides good results in the identification of snow in regional studies (e.g., Magagi and Bernier, 2003; Valenti et al., 2008; Mora et al., 2013), data in the X-band results in better textures determination (Venkataraman et al., 2013), due to its lower penetration capacity and higher spatial resolution. Nevertheless, they are still under evaluation through the use of new platforms such as TerraSAR X, among others. The application of different waves polarization modes (horizontal, vertical or circular) of the transmitted and received signals allows different backscattering, what could be used to distinguish different surface ruggedness and texture, considering that the penetration depth of the radar signal depends on the polarization mode (Carreño, 2014). 
TerraSAR X and his twin TamDEM X satellites (TerraSAR X Ground Segment Basic Product Specification), from the Ministry of Education and Science of the German Government and the AirBus Defense and Space Company, are operatives since 2007 and 2010, respectively, and permits the observation of the Earth by the use of Synthetic Aperture Radar (SAR). For the study of small areas such as the CALM sites in Deception and Livingston Islands, the High Resolution Spotlight mode of the satellites allows to obtain data with $1.2 \mathrm{~m}$ spatial resolution in the "slant range", and $1.1 \mathrm{~m}$ in the "azimuth" for scenes of $5 \times 10 \mathrm{~km}$ in side. This kind of data will make possible (i) to compare (and test) the use of the pictures taken on the surface by the automatic camera, and (ii) to map the snow cover through time for the CALM sites and surrounding areas. In fact, the preliminary works provided good results on the snow cover presence and characterization (e.g. humidity, ruggedness, and/or reflectivity) (Mora et al., 2013; Jiménez, 2014).

Besides, Sentinel 1 satellite from the European Space Agency (operative since 2014) (Sentinel 1 User Handbook) returns a wide variety of products that could be used in the study of the snow cover, mainly the SAR L1 SLC or GRD products (band C, $4.3-4.9 \mathrm{~m}$ azimuth $\mathrm{x} 1.7$ to $3.6 \mathrm{~m}$ range, polarization modes: $\mathrm{HH}+\mathrm{HV}, \mathrm{VH}+\mathrm{VV}, \mathrm{HH}$, $\mathrm{VV})$. These products will allow the development of multitemporal studies useful for the analysis of the snow cover evolution (Longépé et al., 2009). Moreover, information from snow pits at the CALM sites will allow to characterize the snow from radar data (snow grain size, cohesion, water content, or density, among others), which can be used for snow cover mapping.

In summary, the use of radar data in the C- and X-bands will allow the characterization of the snow cover and its variability through time. Together with models of snow microwave radiative transference in the ground, this information is a key factor to understand the evolution of the permafrost (e.g., Wiessman and Mäzler, 1999).

\section{Conclusions}

After nine years of continuous active layer thickness and ground thermal monitoring in Deception and Livingston Islands at two CALM sites and multiple GTN-P stations, we were able to characterize the thermal behavior of the ground, including both the active layer and permafrost. Due to the preliminary observations of the snow cover evolution in the different sites and known the isolation effect of the snow, the next projects will focus on (i) the maintenance of the monitoring sites and their instruments; (ii) the incorporation of new monitoring devices and instruments aiming to obtain the snowpack properties (snow water equivalent, snow thickness, snow temperature, etc.); (iii) the study of the snow cover spatial distribution through the analysis of automatic cameras to correlate the snow cover spatial (and thickness) evolution, and the thermal behavior and active layer thickness evolutions; and (iv) the use of remote sensing (both on optical and radar bands) to upscale the spatial distribution. All these new approaches applied to the study of snow on the South Shetland Islands will improve, not only our knowledge on permafrost and the active layer in our monitoring sites, but also on both islands, contributing to our understanding of the permafrost in Antarctica and their possible change due to the global climate warming. 


\section{Acknowledgements}

This work has been supported by funds from the Ministry of Economy of the Spanish Government through the Polar Research Program (PERMAPLANET CTM200910165-E; ANTARPERMA CTM2011-15565-E; PERMASNOW CTM2014-52021-R) and the PERMATHERMAL arrangement between the University of Alcalá, the Spanish Institute of Geology and Mining, and the Spanish Polar Committee for the maintenance of the monitoring stations in Deception and Livingston Islands. Portuguese contribution was partially supported by the Portuguese Foundation for Science and Technology (PERMANTAR-3 PTDC/AAG-GLO/3908/2012).

\section{References}

Abrams, M., Tsu, H., Hulley, G., Iwao, K., Pieri, D., Cudahy, T., Kargel, J. 2015. The Advanced Spaceborne Thermal Emission and Reflection Radiometer (ASTER) after fifteen years: Review of global products. International Journal of Applied Earth Observation and Geoinformation 38, 292-301.

Andersland, O.B., Ladanyi, B. 1994. An Introduction to Frozen Ground Engineering. Chapman and Hall, New York.

Bañon, M., Vasallo, F. 2015. AEMET en la Antártida: Climatología y meteorología sinóptica en las estaciones meteorológicas españolas en la Antártida. AEMET, Madrid, 152 pp.

Bockheim, J.G. 1995. Permafrost distribution in the Southern Circumpolar Region and its relation to the environment: a review and recommendations for further research. Permafrost and Periglacial Processes 6, 27-45.

Bockheim, J., Vieira, G., Ramos, M., López-Martínez, J., Serrano, E., Guglielmin, M., Wilhelm, K., Nieuwendam, A. 2013. Climate Warming and Permafrost Dynamics in the Antarctic Peninsula Region. Global and Planetary Change 100, 215-223.

Brown, J., Nelson, F.E., and Hinkel, K.M. 2000. The circumpolar active layer monitoring (CALM) program research designs and initial results. Polar Geography 3, 165-258.

California Institute of Technology, 2006. Advanced Spaceborne Thermal Emission and Reflection Radiometer: Instrument Subsystems. Available at: http://asterweb.jpl.nasa.gov/instrument. asp (last access 04/12/2006).

Carreño, F. 2013. Módulo Radar. Master en Tecnologías de la Información Geográfica, Universidad Rey Juan Carlos and Universidad de Alcalá, Alcalá de Henares.

Coleman, T.L., Gudapati, L., Derrington, J. 1990. Monitoring forest plantations using Landsat Thematic Mapper data. Remote Sensing of Environment 33, 211-221.

Correia, A., Ramos, M., Vieira, G. 2012. Thermal conductivity and thermal diffusivity of cores from a 26 meter deep borehole drilled in Livingston Island, Maritime Antarctic Geomorphology 155-156, 7-11.

de Pablo, M.Á., Ramos, M., Vieira, G., Quesada, A. 2010. A new CALM-S site on Byers Peninsula, Livingston Island, maritime Antarctica. In J.J. Blanco, M. Ramos, M.Á. de Pablo (eds.), Proceedings of II Iberian Conference of the International Permafrost Association Periglacial, environments, permafrost and climate variability, Universidad de Alcalá de Henares, pp. 155-162. ISBN: 978-84-9138-885-5.

de Pablo, M.Á., Molina, A., Ramos, M. 2011. Transecto de medición sistemática del espesor de la Capa Activa en las proximidades de la Base Antártica Española Juan Carlos I, Isla Livingston, Antártida. Libro de resúmenes del III Simposio Ibérico de la International Permafrost Association, pp. 119-122. 
de Pablo, M.Á., Blanco, J.J., Molina, A., Ramos, M., Quesada, A., Vieira, G. 2013. Interannual active layer variability at the Limnopolar Lake CALM site on Byers Peninsula, Livingston Island, Antártica. Antarctic Science 25 (2), 167-180.

de Pablo, M.Á., Ramos, M., Molina, A. 2014. Thermal characterization of the active layer at the Limnopolar lake CALM site on Byers Peninsula (Livingston Island), Antarctica. Solid Earth 5, 721-739.

de Pablo, M.Á., Ramos, M., Molina, A. 2016. Snow cover evolution at the Limnopolar Lake CALM-S site on Byers Peninsula, Livingston Island, Antarctica, 2009-2014. Catena. Submitted.

Denis A., Stevens, A., Wesemael, B., Udelhoven, T., Tychon, B., 2014. Soil organic carbon assessment by field and airborne spectrometry in bare croplands: accounting for soil surface roughness. Geoderma 226-227, 94-102.

Engel, Z., Láska, K., Franta, T., Máčka, Z., Marvánek, O. 2010. Recent changes of permafrost active layer on the James Ross Island, Maritime Antarctic. In J.R. Mertes, H.H. Christiansen, B. Etzelmüller (eds.), Abstracts from the Third European Conference on Permafrost, UNIS, Longyearbyen, p. 129.

Escadafal, R. 1993. Remote sensing of soil color: principles and applications. Remote Sensing of Environment 7, 261-279.

French, H.M. 1996. The periglacial environment. John Wiley and Sons, Chichester, UK.

Gómez, A., Palacios, D., Ramos, M., Tanarro, L.M., Schulte, L., Salvador, F. 2001. Location of Permafrost in Marginal Regions: Corral del Veleta (Sierra Nevada, Spain). Permafrost and Periglaciar Processes 12 (1), 93-110.

Goodrich, L.E. 1982. The influence of snow cover on the ground thermal regime. Canadian Geotechnical Journal 19, 421-432.

Hauck, C., Vieira, G., Gruber, S., Blanco, J.J., Ramos, M. 2007. Geophysical identification of permafrost in Livingston Island, Maritime Antarctic. Journal of Geophysical Research 112, F02S19. Doi: 10.1029/2006JF00054.

Hrbáček, F., Láslar, K., Engel, Z. 2014. Thermal regime of permafrost active layer on James Ross Island, Maritime Antarctica in the years 2011 and 2012. IV European Permafrost Conference, Evora, June 2014.

Hrbáček, F., Láska, K., Engel, Z. 2015. Effect of Snow Cover on the Active-Layer Thermal Regime - A Case Study from James Ross Island, Antarctic Peninsula. Permafrost and Periglacial Processes, in press. Doi: 10.1002/ppp.1871.

Hrbáček, F., Oliva, M., Láska, K., Ruiz-Fernández, J., de Pablo, M.Á., Vieira, G., Ramos, M., Nývlt, D. 2016. Active layer thermal regime in two climatically contrasted sites of the Antarctic Peninsula region. Cuadernos de Investigación Geográfica 42 (2), 457-474.

Jiménez, J. 2013. Caracterización de la variabilidad de la capa activa en el entorno de la BAE Juan Carlos I (Antártida). Trabajo de Fin de Grado. Facultad de Biología, Ciencias Ambientales y Química, Universidad de Alcalá.

Jiménez, J. 2014. Metodología para la caracterización de la cobertura nival mediante imágenes TerraSAR X. Aplicación preliminar al sitio CALM Crater Lake, Isla Decepción (Antártida). Master Tesis en Tecnologías de la Información Geográfica, Universidad de Alcalá.

Jiménez, J., Ramos, M., de Pablo, M.Á., Viera, G., Molina, A. 2014. Enthalpic method and microclimatic variability in Livingston Island. A decade of experimental monitoring in the vicinity of SAS Juan Carlos I (Antarctica). In 4th European Conference on Permafrost, Évora, Portugal, 18-21 June 2014.

King, J.C., Turner, J., Marchall, G.J., Connolley, W.M., Lachlan-Cope, T.A. 2003. Antarctic Peninsula Variability and its Causes as revealed by Analysis of Instrumental records. In E. 
Domack, A. Leventer, A. Burnett, R. Bindschadler, P. Convey, M. Kirby (eds.), Antarctic peninsula climate variability, Antarctic research series AGU 79, pp. 17-30.

Láska, K., Nývlt, D., Engel, Z., Budík, L. 2012. Seasonal variation of meteorological variables and recent surface ablation / accumulation rates on Davies Dome and Whisky Glacier, James Ross Island, Antarctica. Geophysical Research Abstracts 14, EGU2012-5545.

Lewkowicz, A.G. 2008. Evaluation of miniature temperature-loggers to monitor snowpack evolution at mountain permafrost sites, northwestern Canada. Permafrost and Periglacial Processes 19, 323-331.

Lipzig, N.P.M., King, J.C., Lachlan-Cope, T.A., van der Broeke, M.R. 2004. Precipitation, sublimation and snow drift in the Antarctic Peninsula region from a regional atmospheric model. Journal of Geophysical Research 109, D24106.

Longepe, N., Allain, S., Ferro-Famil, L., Pottier, E., Durand, Y. 2009. Snowpack Characterization in Mountainous Regions Using C-Band SAR Data and a Meteorological Model. IEEE Transactions of Geoscience and Remote Sensing 47 (2). Doi: 10.1109/TGRS.2008.2006048.

Magagi, R., Bernier, M. 2003. Optimal conditions for wet snow detection using RADARSAT SAR data. Remote Sensing of Environment 84, 221-223.

Malik, M.J., van der Velde, R., Vekerdy, Z., Su, S. 2012. Assimilation of satellite-observed snow albedo in a land Surface model. Journal of Hydrometeotrology 12, 1119-1130.

Matsuoka, N. 2006. Monitoring periglacial processes: Towards construction of a global network. Geomorphology 80, 20-31.

Milani, G. 2014. Pic2Map: intégration de photographies dans QGIS. Master Thesis. École Polytechnique Fédérale de Lausanne.

Molina, A., de Pablo, M.Á., Ramos, M., Vieira, G. 2011. Estudio del efecto de la cobertura nival sobre los periodos de congelación-descongelación en el entorno de la Base Antártica Española Juan Carlos I. Libro de resúmenes del III Simposio Ibérico de la International Permafrost Association, pp. 87-92.

Mora, C., Viera, G., Ramos, M. 2013. Evaluation of Envisat ASAR IMP imagery for snow mapping at varying spatial resolution (Deception Island, South Shetlands-Antarctica). In M. Hambrey (ed.), Antarctic Glacial and Periglacial Processes, The Geological Society Publications, London (in press).

Nelson, F.E, Shiklomanov, N.I. 2009. The Circumpolar Active Layer Monitoring Network-CALM III (2009-2014): Long-term Observations on the Climate-Active Layer-Permafrost System. In Ambientes periglaciares, permafrost y variabilidad climática, Universidad de Alcalá, Alcalá de Henares, pp. 9-14.

Produit, T., Tuia, D. 2012. An open tool to register landscape oblique images and generate their synthetic models. In Open Source Geospatial Research and Education Symposium (OGRS), Yverdon-les-Bains, Switzerland, 24 ${ }^{\text {Th }}-26^{\text {Th }}$ October 2012.

Ramos, M. 1995. Automatic Device to Measure the Active Permafrost Layer near the Spanish Antarctic Station. Terra Antarctica 2 (1), 61-63.

Ramos, M. 1997. Topographic Distribution of Short-wave Radiation in the surroundings of the Spanish Antarctic Station Austral summers 1992, 1993, 1994. Terra Antartica 4 (1), 5-10.

Ramos, M. 1998. Active Layer in the vicinity of the Spanish Antarctic Station. Terra Antartica 5 (2), 189-193.

Ramos, M., Vieira, G. 2004. Variabilidad térmica de la capa activa y evaluación de la energía perdida por el suelo durante el proceso de congelación en la isla Livingston (Antártida). Inviernos 2000, 2001 y 2002. Boletín de la Real Sociedad Española de Historia Natural (Sec. Geología) 99, 83-92.

Ramos, M., Vieira, G. 2008. Evaluation of the ground surface enthalpy balance from bedrock temperatures (Livingston Island, Maritime Antarctic). The Cryosphere 3, 133-145. 
Ramos, M., Vieira, G., Blanco, J.J., Gruber, S., Hauck, C., Hidalgo, M.A., Tomé, D. 2008. Thermal active layer monitoring in two different sites on Livingston Island during the last seven years: a comparative study. In Proceedings of the 9th International Conference on Permafrost, Fairbanks, Alaska. Institute of Northern Engineering, University of Alaska Fairbanks, pp. 1463-1467.

Ramos, M., Hassler, A., Vieira, G., Hauck, C., Gruber, S. 2009. Drilling and installation of boreholes for permafrost thermal monitoring on Livingston Island in the Maritime Antarctic. Permafrost and Periglacial Processes 20 (1), 57-64.

Ramos, M., de Pablo, M.Á., Vieira, G., Molina, A. 2011a. Estado térmico del permafrost y evolución de la capa activa en la experiencia CALM-S (Crater Lake) (Isla Decepción). Libro de resúmenes del III Simposio Ibérico de la International Permafrost Association, pp. 95100.

Ramos, M., de Pablo, M.Á., Vieira, G., Molina, A. 2011b. Monitorización sistemática de la evolución térmica del permafrost en las proximidades de las bases antárticas españolas basada en los protocolos CALM-S y TSP. Libro de resúmenes del III Simposio Ibérico de la International Permafrost Association, pp. 101-104.

Ramos, M., de Pablo, M.Á., Molina, A., Vieira, G., Trindade, A., Correia, A. 2012a. Análisis de los ciclos de congelación y descongelación en la capa activa en el entorno de la BAE JCI. Periodo 2000-2011. $7^{a}$ Asamblea Hispano Portuguesa de Geodesia y Geofísica, Donostia, Julio-2012, Ed. Aranzadi, pp. 723-726.

Ramos, M., de Pablo, M.Á, Molina, A., Vieira., G. 2012b. Progresión del frente de hielo en la capa activa de la experiencia CALM-S "Crater Lake" (Isla Decepción, Antártida). $7^{a}$ Asamblea Hispano Portuguesa de Geodesia y Geofísica, Donostia, Julio-2012, Ed. Aranzadi, pp. 727730 .

Rees, G. 2006. Remote sensing of snow and ice. CRC Press, Boca Raton, pp. 99-156.

Sentinel-1 User Handbook. GMES-S1OP-EOGP-TN-13-0001. 1st September 2013. European Space Agency (ESA).

Tanarro, L.M., Hoelzle, M., García, A., Ramos, M., Gruber, S., Gómez, A., Piquer, M., Palacios, D. 2001. Permafrost Distribution Modelling in the Mountains of the Mediterranean: Corral del Veleta, Sierra Nevada, Spain. Norsk Geografisk Tidsskrift 55, 253-260.

Tedstone, A.J., Nienow, P.W., Gourmelen, N., Dehecq, A., Goldberg, D., Hanna, E. 2015. Decadal slowdown of a land-terminating sector of the Greenland Ice Sheet despite warming. Nature 526, 692-695.

TerraSAR-X Ground Segment Basic Product Specification Document. CAF - Cluster Applied Remote Sensing. TX-GS-DD-3302, Issue 1.9, Date: 09.10.2013. TerraSAR-X Services Image Product Guide. Basic and Enhanced Satellite Imagery. Issue 1.0 InfoTerra GmbH 12/2009.

Turner, J., Colwell, S.R., Marshall, G.J., Lachlan-Cope, T.A., Carleton, A.M., Jones, P.D., Lagun, V., Reid, P.A., Lagovkina, S. 2005. Antarctic climate change during the last 50 years. International Journal of Climatology 25, 279-294.

Turner, J., Bindschadler, R., Convey, P., Di Prisco, G., Fahrbach, E., Gutt, J., Hodgson, D., Mayewski, P., Summerhayes, C. 2009. Antarctic climate change and the environment. Scientific Committee on Antarctic Research. Cambridge, UK.

Turner, J., Barrand, N.E., Bracegirdle, T.J., Convey, P., Hodgson, D.A., Jarvis, M., Jenkins, A., Marshall, G., Meredith, M.P., Roscoe, H., Shanklin, J., French, J., Goosse, H., Guglielmin, M., Gutt, J., Jacobs, S., Kennicutt II, M.C., Masson-Delmotte, V., Mayewski, P., Navarro, F., Robinson, S., Scambos, T., Sparrow, M., Summerhayes, M., Speer, M., and Klepikov, A. 2013. Antarctic climate change and the environment: an update. Polar Record 50 (3), 237259. 
Urban, M., Eberle, J., Hüttich, C., Schmullius, C., Herold, M. 2013. Comparison of SatelliteDerived Land Surface Temperature and Air Temperature from Meteorological Stations on the Pan-Arctic Scale. Remote Sensing 2013-5, 2348-2367.

Valenti, L., Small, D., Meier, E. 2008. Snow cover monitoring using multi-temporal Envisat/ASAR data. Proccedings of 5th EARSeL LISSIG (Land, Ice, Snow) Workshop, Bern, Switzerland.

Vaughan, D.G., Marshall, G., Connolley, W.M., Parkinson, C., Mulvaney, R., Hodgson, D.A., King, J.C., Pudsey, C.J., Turner, J., Wolff, E. 2003. Recent rapid regional climate warming on the Antarctic Peninsula. Climate change 60, 243-274.

Venkataraman, G., Singh, G., Kumar, V. 2013. Snow cover area monitoring using multi-temporal TerraSAR-X data. Available at: http:IIsss.terrasar-x.dlr.de/papers_sci_meet_3/poster / LAN0122_Venkataraman.pdf

Vieira, G., Bockheim, J., Guglielmin, M., Balks, M., Abramov, A., Boelhouwers, J., Cannone, N., Ganzert, L., Gilichinsky, D., Goryachkin, S., López-Martínez, J., Meiklejohn, I., Raffi, R., Ramos, M., Schaefer, C., Serrano, E., Simas, F., Sletten, R., Wagner, D. 2010. Thermal state of permafrost and active-layer monitoring in the Antarctic: advances during the International Polar Year 2007-2009. Permafrost and Periglacial Processes 21, 182-197.

Vieira, G., Ramos, M., Mora, C., Rocha, M.J., Trigo, I., de Pablo, M.Á. 2011a. Active layer thermal regime in Hurd Peninsula (Livingston Island, Antarctic) from 2000-2010. Mesoscale forcing mechanisms. Libro de resúmenes del III Simposio Ibérico de la International Permafrost Association, 105-106

Vieira, G., Mora, C., Neves, M., Oliva, M., Batista, V., Ferreira, A., Jorge, M., Trindade, A., Correia, A., Maillol, J.M., Amaral, P., Santos, F., Bernardo, I., Soares, A., Ramos, M., de Pablo, M.Á., Bockheim, J., Caselli, A., Goyanes, G., Schaeffer, C., Simas, F., Pimpirev, C., Kenderova, R. 2011b. Permafrost and Climate Change in the Maritime Antarctic (PERMANTAR-2). Libro de resúmenes del III Simposio Ibérico de la International Permafrost Association, pp. 147-150.

Viscarra Rossel, R.A., Minasny, B., Roudier, P., McBratney, A.B. 2006. Colour space models for soil science. Geoderma 133 (3), 320-337.

Weyant, W.S. 1966. The Antarctic climate. In J.C.F. Tedrow (ed.), Antarctic Soils and Soil Forming Processes. American Geophysical Union, Antarctic Research Ser. 8, 47-59.

Wiesmann, A., Mätzler, C. 1999. Microwave emission model of layered snowpacks. Remote Sensing of Environment 70 (3), 307-316.

Williams, P.J. 1995. Permafrost and climate change: geotechnical implications. Philosophical Transactions of the Royal Society of London A 352 (1699), 347-358.

Zhang, T., Osterkamp, T.E., Stammes, K. 1996. Influence of the depth hoar layer of seasonal snow cover on the ground thermal regime. Water Resources Research 32 (2), 2075-2086.

Zhang, T. 2005. Influence of the seasonal snow cover on the ground thermal regime: An overview. Review of Geophysics 43 RG4002. Doi: 10.1029/2004RG000157. 